\title{
Effects of Oral Cadmium Exposure on Renal Glomerular and Tubular Functions in the Rat
}

\author{
${ }^{1 *}$ ASAGBA, S O; ${ }^{2}$ OBI, F O \\ ${ }^{1}$ Department of Biochemistry, Faculty of Science, Delta State University, Abraka, Nigeria \\ ${ }^{2}$ Department of Biochemistry, Faculty of Science, University of Benin, Benin City, Nigeria
}

\begin{abstract}
The effects of orally consumed cadmium on the functions of the kidney have been investigated in rats based on the reported level of the toxicant in Warri River. Relative to the corresponding controls there were significant $(\mathrm{P}<0.05)$ increases in the amount of cadmium in the kidneys of rats in all the test groups. Biochemical analysis revealed significant $(\mathrm{P}<0.05)$ changes in plasma creatinine after 2 months (control $-1.20 \pm 0.20 \times 10^{-2}$; test $-0.92 \pm 0.26 \times 10^{-2} \mu \mathrm{g} / \mathrm{ml}$ ) and glucose after 1-month (control $-91.67 \pm 3.39$; test $-102.75 \pm 5.99 \mathrm{mg} / \mathrm{dL}$ ) exposure. Twenty-four hours urine volume were significantly decreased $(\mathrm{P}<0.05)$ in rats exposed to cadmium for 1 and 2 months. Also in the Cd-exposed rats urine protein was significantly elevated in those exposed for 2 and 3 months but their urine glucose was demonstratively elevated only in those exposed for 2 months (control $-33.00 \pm 7.80$; test $43.00 \pm 9.80 \mathrm{mg} / \mathrm{dL}$ ). Urine creatinine was not significantly altered in any of the test groups. Consistently there were significant $(\mathrm{P}<0.05)$ decreases in total ATPase and $\mathrm{Mg}^{2+}$ - ATPase activities at the end of the 2 and 3 months exposure when compared to the controls @JASEM
\end{abstract}

The kidneys and liver are among the major target organs of cadmium (Cd) accumulation and intoxication (WHO report, 1992). The presence of cadmium in all links of the food chain, poor excretability, propensity for bioaccumulation and persistence make it a source of considerable risk to human health (Cabrera et al., 1998) vis-à-vis the functional integrity of the two organs indicated above and others. Cd-induced injury to both organs has been attributed to its ability to enhance free radical formation in vivo (Gupta et al., 1991; Bagchi et al., 1996). Some characteristic biochemical features associated with Cd-induced kidney damage are urinary excretion of protein, $\mathrm{N}$-acetyl $-\beta-\mathrm{D}-$ glucosaminidase, glucose and amino acids. Others are marked increase of plasma creatinine or blood urea nitrogen levels (Horiguchi et al., 1996) as well as altered plasma glucose level (Chapatwala et al., 1980). Consumption of contaminated water is the major way by which humans are exposed to $\mathrm{Cd}$ (WHO report, 1992) and the maximum allowable level in drinking-water is $0.005 \mathrm{mg} / \mathrm{dL}$ (WHO report, 1984). In many countries including Nigeria contamination of rivers and adjoining seas by $\mathrm{Cd}$ and other heavy metals occurs in a number of ways among which is the discharge of waste liquid matter from industrial sites. The average level of $\mathrm{Cd}$ in Warri River waters between 1986 and 1991 was 0.3mg/L (Egborge, 1994). This is 60 - fold above the maximum allowable level in drinking water. Naturally this is worrisome. Therefore this paper focuses on the toxicity of $\mathrm{Cd}$ in rats, which can be related to the Warri River level of the toxicant within the period in question.

*Corresponding author: E-mail:

Abstracts available Online at http://www.ajol.info

\section{MATERIALS AND METHODS}

Animals: Thirty-six adult albino rats (Wistar strain), 180 - 190g, bred in the Animal Unit of the School of Pharmacy, University of Benin were used for this study.

Chemicals and reagents: Bovine serum albumin, cadmium sulphate $\left(3 \mathrm{CdSO}_{4} \cdot 8 \mathrm{H}_{2} \mathrm{O}\right)$, chloroform and sodium hydroxide were purchased from May and Baker, Dagenham, England. Adenosine triphosphate (disodium salt) was purchased from Sigma Chemical Company, U.S.A. Glucose oxidase kit was obtained from QCA (Spain).

Treatment of animals: The rats were divided into six experimental groups of six rats each and housed in standard rat cages. From these, three subgroups made up of two cages of rat each were produced. One set of rats in a subgroup served as the control while the other served as the test. The control groups were provided with distilled water as drinking-water while the test groups were provided with aqueous solution of $\mathrm{CdSO}_{4}$ containing the equivalent of $0.30 \mathrm{mg} \mathrm{Cd} / \mathrm{L}$ for one, two and three months respectively. All rats were allowed free access to chow (BFFM, Ewu, Nigeria).

Animal sacrifice and tissue preparation: After the specified period of exposure rats in each subgroup were transferred to metabolic cages equipped with accessory for collecting urine. The 24 hours urine samples were collected after which each rat was anaesthetized with chloroform. While under anaesthesia blood samples were obtained via heart puncture and transferred to heparinized tubes standing on ice. The kidneys were excised. Plasma was obtained by centrifugation at $3000 \mathrm{rpm}$ for 10 minutes. The kidneys were homogenized as described by Adam - Vizi and Seregi (1982). 
Biochemical assays: The activities of ATPases in the kidney homogenates were assayed as described by Adam - Vizi and Seregi (1982). Protein content of the homogenate and urine was measured by the Lowry method as described previously (Obi et al., 1998). Plasma and urine glucose estimation was based on the glucose oxidase assay procedure described in the QCA kit instruction leaflet. Plasma and urine creatinine levels were determined by the Jaffe reaction in which a coloured product is formed from creatinine and picric acid in alkaline solution. Cadmium analysis: Kidney cadmium content was estimated with atomic absorption spectrophotometer (Varian AA 1475) after wet digestion of the tissues. For the digestion, 20ml $\mathrm{HNO}_{3}-\mathrm{HCLO}_{4}$ mixture (4:1) was introduced into a beaker containing $1 \mathrm{~g}$ of a given kidney sample followed by heating at $100^{\circ} \mathrm{C}$ until the sample was completely dissolved. Each digest was thereafter diluted to $100 \mathrm{ml}$ with distilled deionized water.

Statistical analysis: The data are presented as means $\pm \mathrm{SD}$. The mean values of the control and test groups were compared using Student's t-test. The significant level was set at $\mathrm{P}<0.05$.

\section{RESULTS AND DISCUSSION}

In this study we provided water and a solution of $\mathrm{CdSO}_{4}(\equiv 0.30 \mathrm{mg} \mathrm{Cd} / \mathrm{L})$ ad libitum to rats for oral consumption for 1, 2 and 3 months. At the end of each period of exposure the state of various plasma and urine parameters normally used as indicators of the proper functioning of the kidney were assessed. Changes in rat kidney $\mathrm{Cd}$ load caused by this treatment are presented in table 1.

Table 1. Cadmium concentration in Kidney and Cd-exposed rats (mean \pm sd); $n=6$

\begin{tabular}{lll}
$\begin{array}{l}\text { Duration of } \\
\text { exposure (month) }\end{array}$ & Concentration of Cd in kidney $\left(\mu \mathrm{g} \times 10^{-3}\right)$ \\
\hline & $\frac{\text { Control (- Cd) }}{2.1 \pm 0.07}$ & $\frac{\text { Test }(+\mathrm{Cd})}{6.70 \pm 0.20^{*}}$ \\
1 & $6.80 \pm 0.60$ & $28.00 \pm 5.00^{*}$ \\
2 & $11.00 \pm 6.00$ & $56.00 \pm 8.21^{*}$ \\
\hline
\end{tabular}

*Values statistically significant from control $(\mathrm{P}<0.05)$

The data in table 2 show the results of the analysis of plasma parameters while that in table 3 represent the values for urine parameters. Table 4 shows the results of total ATPase, $\mathrm{Mg}^{2+}-$ ATPase and $\mathrm{Na}^{+}-\mathrm{K}^{+}$ ATPase assay. The results presented in table 1 for kidney Cd load reveals that the control rats were not Cd-free. At the end of the first month of exposure kidneys from the control rats had $0.021 \mu \mathrm{g} \mathrm{Cd} / \mathrm{g}$. By the end of 2 and 3 months the kidney load has increased to 0.068 and $0.11 \mu \mathrm{g} / \mathrm{g}$ respectively. The second and third month values represent an increase of 223.8 and 423.8 percent over and above the 1 month value. The presence of $\mathrm{Cd}$ in the kidney of the control rats and the progressive manner in which it increased are indications that their water and/or feed were tainted with $\mathrm{Cd}$. This is not surprising in view of the wide distribution of $\mathrm{Cd}$ in the general environment today. It is conceivable though that the result of our investigation is likely to be affected by the presence of $\mathrm{Cd}$ in the kidney of control rats.
While this is not unlikely it is pertinent to note that reproducible results were obtained by Horiguchi et al. (1996) who had the same problem. In their study they administered supposedly Cd-free saline solution to control rats, subcutaneously, once a week and detected $0.041 \pm 0.016$ and $0.065 \pm 0.009 \mu \mathrm{g} \mathrm{Cd} / \mathrm{g}$ kidney at the end of the 6 and 9 months exposure period respectively. Evidently the sodium chloride and/or water (the basic components of the saline) and/or the feed on which the control rats were maintained must have been tainted with $\mathrm{Cd}$. Again our test rats were provided with $\mathrm{CdSO}_{4}$ solution prepared with the same distilled water that was provided as drinking water for the control rats. Both group of rats were also maintained on the same rat chow. Evidently the control and the test rats likely had identical baseline Cd level and effects or the same incremented build up of Cd from any other source upon which the load and effects due to $\mathrm{CdSO}_{4}$ consumption will be distinctly superimposed.

Table 2. Volumes and biochemical parameters of urine from control and Cd-exposed rats (mean $\pm \mathrm{sd}$ )

\begin{tabular}{|c|c|c|c|c|c|c|c|c|}
\hline \multirow{2}{*}{$\begin{array}{l}\text { Duration of } \\
\text { exposure } \\
\text { (month) }\end{array}$} & \multicolumn{2}{|c|}{ A } & \multicolumn{2}{|c|}{ B } & \multicolumn{2}{|c|}{ C } & \multicolumn{2}{|c|}{ D } \\
\hline & $\mathrm{X}$ & Z & $\mathrm{X}$ & $\mathrm{Z}$ & $\mathrm{X}$ & Z & $\mathrm{X}$ & Z \\
\hline 1 & $14.0 \pm 2.7$ & $10.3 \pm 1.8 *$ & $5.74 \pm 0.13$ & $5.06 \pm 0.9$ & $36.0 \pm 1.7$ & $35.0 \pm 1.20$ & $68.0 \pm 21.0$ & $80.0 \pm 23.4$ \\
\hline 2 & $13.1 \pm 1.7$ & $8.1 \pm 2.5^{*}$ & $8.1 \pm 0.22$ & $10.2 \pm 1.1^{*}$ & $33.0 \pm 7.8$ & $43.0 \pm 9.8 *$ & $32.0 \pm 6.9$ & $25.3 \pm 7.5$ \\
\hline 3. & $8.2 \pm 3.7$ & $6.2 \pm 1.1$ & $5.6 \pm 0.15$ & $9.64 \pm 0.06 *$ & $14.0 \pm 7.1$ & $11.1 \pm 8.0$ & $94.0 \pm 14.2$ & $81.3 \pm 29.0$ \\
\hline
\end{tabular}

* Values statistically significant different from control $(\mathrm{p}<0.005) . \mathrm{A}=24 \mathrm{~h}$ urine volume $(\mathrm{ml}), \mathrm{n}=5$; $\mathrm{B}=$ urine protein conc. $(\mathrm{mg} / \mathrm{day}), \mathrm{n}=$

5: $\quad C=$ urine glucose conc. $(\mathrm{mg} / \mathrm{dL}), \mathrm{n}=6 ; \mathrm{D}=$ urine creatine conc. $(\mathrm{ug} / \mathrm{mL}), \mathrm{n}=6 ; \mathrm{X}=$ control $(-\mathrm{Cd}) ; \mathrm{Z}=$ test $(+\mathrm{Cd})$ 
Twenty-four hour urine volume, urinary protein, glucose, amino acid and $\mathrm{N}$-acetyl $-\beta-\mathrm{D}-$ glucosaminidase are usually studied as indices of the functional integrity of renal proximal tubules while proper glomerular function is assessed by examining the plasma creatinine or blood urea nitrogen level (Friberg et al., 1986). In the present study we examined urine volume, urinary protein and glucose as well as plasma creatinine. We found that $24 \mathrm{~h}$ urine volumes were significantly $(\mathrm{P}<0.05)$ decreased in the test rats at the end of 1 and 2 months respectively (Table 2). Urine proteins were, however, significantly $(\mathrm{P}<0.05)$ increased in the test rats at the end of 2 and 3 months respectively.
Significant $(p<0.05)$ increase in glucose was demonstrated in the urine of the test rats exposed to $\mathrm{Cd}$ for 2 months. Increased urine protein and glucose levels were observed at the end of 2 months of oral Cd exposure. Proteinuria has been observed in man and animals and shown to be due to renal tubular dysfunction (Friberg et al., 1986; Horiguchi et al., 1996). Evidently bioaccumulation of cadmium in the kidney of the test rats appreciated to a point (by the end of the second month in particular) where it caused proteinuria and glucosuria, two conditions which in combination with others are evidences of renal tubular dysfunction.

Table 3. Plasma creatine and glucose in control and Cd-exposed rats (mean \pm sd); $\mathrm{n}=6$.

\begin{tabular}{lllll}
\hline Duration of & \multicolumn{2}{l}{ Creatine conc. ug/ml x $10^{-2}$} & \multicolumn{2}{l}{ Glucose conc. $(\mathrm{mg} / \mathrm{dL0}$} \\
\cline { 2 - 4 } exposure (month) & Control (-Cd) & Test $(+\mathrm{Cd})$ & Control $(-\mathrm{Cd})$ & Test $(+\mathrm{Cd})$ \\
1 & $6.6 \pm 1.2$ & $7.6 \pm 1.5$ & $91.7 \pm 3.4$ & $102.8 \pm 6.0^{*}$ \\
2 & $1.2 \pm 0.2$ & $0.9 \pm 0.3^{*}$ & $106.0 \pm 9.5$ & $100.0 \pm 1.8$ \\
3 & $6.8 \pm 1.4$ & $6.6 \pm 0.7$ & $91.9 \pm 3.2$ & $91.4 \pm 1.96$ \\
\hline * Values statistically significantly different from control $(\mathrm{p}<0.05)$
\end{tabular}

In our study $24 \mathrm{~h}$ urine volume did not increase but decreased in the test rats. Urinary protein was increased in the test rats only at the end of 2 and 3 months. Urinary glucose was significantly increased in the test rat only at the end of 2 months exposures. Relative to the controls Horiguchi et al. (1996) observed significant increase in $24 \mathrm{~h}$ urine volume, urinary protein and glucose at the end of their 6 and 9 months exposure periods. The absence of increased urine volume and lack of consistency in the increase of protein and glucose in the urine as reported here are likely attributable to the low level of cadmium in the kidney of our test rats. As is evident in table 1, the 2 and 3 months test kidney Cd load were $28.00 \pm$ $5.00 \times 10^{-2}$ and $56.00 \pm 8.21 \times 10^{-2} \mu \mathrm{g} / \mathrm{g}$ respectively whereas the 6 and 9 month test kidney Cd load reported by Horiguchi et al. (1996) were $163.2 \pm 5.0$ and $134.3 \pm 3.8 \mu \mathrm{g} / \mathrm{g}$ respectively.

Plasma creatinine or blood urea nitrogen is used for assessing renal glomerular function. In this study we assessed the level of creatinine for this purpose. Our results show no difference in plasma creatinine level between the control and test groups at the end of the first and third months of exposure. At the end of 2 months of exposure plasma creatinine was significantly $(\mathrm{P}<0.05)$ decreased relative to the control. Absence of increased plasma creatinine indicates that renal glomerular function was not compromised in this study. Our finding is apparently in agreement with that of Horiguchi et al. (1996). Their treatment failed to produce pronounced difference in plasma creatinine between the control and test at the end of their exposure periods. Interestingly at the end of their first exposure period plasma creatinine of the Cd-exposed rats was lower than that of the control rats. This is very much like our finding at the end of 2 months of exposure although the decrease in our own case was significant. Taken together, therefore, our results provide partial evidence of tubular rather than glomerular dysfunction - occasioned by oral consumption of water containing $0.3 \mathrm{mg} \mathrm{Cd} / \mathrm{L}$.

Table 4. Activity of Renal ATPase in control and Cd-exposed Rats ( M e a $n \pm$ S D ; $n=6$ )

Duration of
exposure (month)

$*$ Values statistically significantly different from corresponding control $(\mathrm{p}<0.05)$

$\mathrm{X}=$ control $(-\mathrm{Cd})$ and $\mathrm{Z}=$ test $(+\mathrm{Cd})$ 
Our $24 \mathrm{~h}$ urine volumes at the end of 1 and 2 months exposure periods were significantly $(\mathrm{P}<0.05)$ decreased (Table 2). Extracellular fluid (ECF) volume is influenced by the movement of $\mathrm{Na}^{+}$into and out of a cell. Increased ECF osmolarity decreases renal water excretion (Abraham and Schrier, 1997). Water and $\mathrm{Na}^{+}$movement across plasma membrane is controlled by a transmembrane enzyme, $\mathrm{Na}^{+}-\mathrm{K}^{+}$ATPase, one of a number of “pump” enzymes (Voet and Voet, 1995). In order to obtain a possible explanation for our Cd-induced reduction in $24 \mathrm{~h}$ urine volume we assayed for the activity of total ATPase, $\mathrm{Mg}^{2+}-$ ATPase and $\mathrm{Na}^{+}-$ $\mathrm{K}^{+}$- ATPase in the kidney homogenates. We found that total ATPase and $\mathrm{Mg}^{2+}$ - ATPase activities were significantly reduced in $\mathrm{Cd}$ - exposed rats at the end of 2 and 3 months exposure (Table 4 ). $\mathrm{Na}^{+}-\mathrm{K}^{+}-$ ATPase activity was not altered. It does appear then that the $\mathrm{Cd}$ - induced low $24 \mathrm{~h}$ urine volume is not brought about by altered $\mathrm{Na}^{+}-\mathrm{K}^{+}$- ATPase activity. All the same others (Nishiyama et al., 1986) have reported that $\mathrm{Cd}$ exposure increases sodium and water retention, low urine volume. However, Horiguchi et al. (1996) observed increased 24 h urine volume among Cd-exposed rats. It is therefore obvious that the factors that influence Cd-induced alteration in $24 \mathrm{~h}$ urine volume in man and animals are yet to be clearly established and deserves further investigation.The kidney is the critical target organ in man when subjected to long-term exposure to low or high doses of cadmium. The results presented here suggest that in rats, consumption of $0.3 \mathrm{mg} \mathrm{Cd} / \mathrm{L}$, the level of the toxicant in Warri River between 1986 and 1991 (Egborge 1994) brought about partial tubular dysfunction after 2 months of exposure. Therefore, barring any species difference continuous consumption of water contaminated with cadmium to the extent reported by Egborge (1994) will likely cause some degree of renal tubular dysfunction.

\section{REFERENCES}

Abraham W.T., Schrier R.W. (1997). Renal sodium excretion, oedematous disorders and diuretic use. In: Schrier R.W. (ed). Renal and electrolyte disorders, $5^{\text {th }}$ Edn. Lippincott - Raven publishers. Philadelphia, p $72-130$.
Adam-Vizi V., Seregi M. (1982). Receptor dependent stimulatory effect of noradrenalin on $\mathrm{Na}^{+} / \mathrm{K}^{+}-$ATPase in rat brain homogenate. Role of lipid peroxidation. Biochem. Pharmacol. 31: $2231-2236$.

Cabrera C., Ortega E., Lorenzo M., Lopez M. (1998). Cadmium contamination of vegetable crops, farmlands, and irrigation waters. Rev. Environ. Contam. Toxicol. 154: $55-81$.

Chapatwala D.K., Rajanna B., Desaiah D. (1980). Cadmium - induced changes in gluconeogenic enzymes in rat kidney and liver. Drug Chem. Toxicol. 3(4): $407-420$.

Egborge A.B.M. (1994). Water pollution in Nigeria. Biodiversity and Chemistry of Warri River. Ben Miller Books, (Nig) Ltd., Warri.

Horiguchi H., Sato M., Konno N., Fukushima M. (1996). Long-term cadmium exposure induces anaemia in rats through hypoinduction of erytrhopoietin in the kidney. Arch. Toxicol. 71: $11-19$.

Nishiyama S., Nakamura K., Konishi Y. (1986). Blood pressure and urinary sodium and potassium excretion in cadmium treated male rats. Environ. Res. 40: 357 - 364.

Obi F.O., Usenu, I.A., Osayande J.O. (1998). Prevention of carbon tetrachloride-induced hepatotoxicity in the rat by $\mathrm{H}$. rosasinensis anthocyanin extract administered in ethanol. Toxicology 131: 93 - 98.

Voet D., Voet J.G.(1995). Biochemistry, $2^{\text {nd }}$ Edn. John Wiley and Sons, Inc. New York, USA.

WHO Report. (1984). Guidelines for drinking water quality. Health criteria and other supporting information. World Health Organisation. Geneva pp. 84-90

WHO report (1992). Environmental Health Criteria. 134, Cadmium. World Health Organization, Geneva. 